\title{
Prevalence of Six Viruses in Potato Seed Tubers Produced in Informal Seed System in the North West Region of Cameroon
}

\author{
P. A. Njukeng ${ }^{\star 1}$, G.M. Chewachong ${ }^{1}$, P. Sakwe², G. Chofong ${ }^{1}$, L.W. Nkeabeng 3 , P. Demo ${ }^{4}$, K.D.Njualem³, \\ 1Department of Plant Biology, Faculty of Science, B.P. 67, University of Dschang, Cameroon. \\ ${ }^{2}$ Department of Crop Protections, Faculty of Agriculture and Agronomic Sciences, University of Dschang,Cameroon. \\ 3 Institute of Agricultural Research and Development (IRAD), Bambui, North West Province, Cameroon. \\ ${ }^{4}$ International Potato Centre (CIP) Lilongwe, PO Box 30258, Lilongwe 3, Malawi. \\ ${ }^{*}$ Corresponding author: Dr A. P. Njukeng, E-mail: pnjukeng@yahoo.com
}

\begin{abstract}
Potato (Solanum tuberosum L.) is an important cash-food crop, which is widely grown in three of the five agro-ecological zones of Cameroon. A study was carried out to determine the prevalence of PVA, PLRV, PVM, PVS, PVX and PVY in 1175 sprouted potato seed tubers of different diameters collected from four seed stores in the North West Region of Cameroon. The study also sorts to ascertain variations in virus incidence in small, medium and large size sprouted tubers prior to planting. The DAS-ELISA method was used to test for the presence of these viruses. Results showed significant differences in the prevalence of the six viruses with PVM being the most prevalent (92\%), while PLRV was least prevalent $(35 \%)$ in all the four seed stores sampled. Upper-Farm store registered the highest relative prevalence $(82 \%)$, with PVM detected in all the tubers while samples from Rock-Farm store showed the least relative incidence (55\%) with no PLRV detected. Viruses were significantly most prevalent in small size tubers (71\%) and least in large size potato tubers (63\%). Our results suggest that tuber size can serve as a guide to identify healthy (virus-free) tubers. Farmers could therefore use large size potato tubers for planting.
\end{abstract}

Keywords: DAS-ELISA; healthy seed tubers; Solanum tuberosum; virus prevalence

\section{INTRODUCTION}

Potato (Solanum L.) is an important food crop currently grown at a significant scale in more than 130 countries including Cameroon, covering about 18 million hectares (1). The average world farm yield for potato was 17.4 tons per hectare, in 2010 (2). The yearly production of potato amounts to 295 million tons accounting for about half the yearly world production of roots and tubers, one third of which is from developing countries. It is a short season, high-value crop, grown as a cash crop and for household consumption. Its production in Africa nearly tripled over the past 35 years, from 1.3 million tons in the early 1960 s to 3.7 million tons in $1996(3 ; 4)$. Potato has a high nutritive value and the ratio of protein to carbohydrates is higher than that of most other food crops (5). It is used for human consumption, animal feed, and as a source of starch and alcohol (6). Its role in the market economy in Cameroon has increased, due to demand for root and tuber food crops from neighboring countries like Gabon and Central African Republic (7). The crop has now assumed a cash-food crop status, with an annual tonnage of 150000 tones, grown on 70000 ha of the national territory. More than $70 \%$ of the women in the North West Region of Cameroon are involved in potato cultivation (8). Unfortunately, potato is prone to attack by diseases caused by bacteria, fungi, nematodes and viruses. Among diseases, those caused by viruses are the least known and most difficult to control though they cause significant threats to potato production (9). Important viral potato diseases in Cameroon are PLRV, PVY, PVA, PVX, PVS and PVM (1). These potato viruses are naturally transmitted in three ways: by contact between infected and healthy plant parts, by vectors (insects) with which the viruses associate in a specific manner; and finally through plant parts used for propagation since potato is vegetatively propagated (10). A report by (11) stipulates that the most important means of virus transmission in potato is through infected seed tubers. Most potato viruses are of major economic importance because of losses caused by secondary infection, which occurs when infected seed tubers are planted (12). A direct link 
Njukeng et al, Prevalence of Viruses in Potato Seed Tubers in the North West Region of Cameroon

therefore exists between the quality of seed tubers planted and the productivity of the crop (1) There is paucity of information on pre-planting detection of potato viruses in sprouted tubers, despite the fact that sensitive ELISA tests have been developed and extensively applied in laboratory testing. The development of effective control measures for potato viruses must include the application of efficient virus testing methods in screening potato seeds before planting. It is possible to obtain virus-free seeds through preplanting screening of sprouted tubers. Planting of virus-free tubers will likely reduce the number of virus source plants, reducing virus infection within and across the cropping season $(13 ; 14)$.

The objective of this study was to establish the prevalence rate of six potato viruses that can be used to design control measures for the selection of virus free seeds for the next planting season.

\section{MATERIALS AND METHODS}

\section{Sample collection}

Samples were collected from farms in the North West Region, within the Western Highlands of Cameroon. Four potato seed stores located in Upper Farms Bambui, Ruhvitangtah in Banso, Rock Farm and Wara Farm in Santa, all in the North West Region of Cameroon, were visited and a total of 1175 potato tubers of variety CIPERA were collected. A potato seed multiplication unit of the Institute of Agricultural Research runs the Upper Farms in Bambui for Development, while the other three are private owned.

In each store, tubers were already classified into three sizes (1-3); 1) large, diameter $>8 \mathrm{~cm}$; 2) medium, about $5.5 \mathrm{~cm}$; and 3) small, about $3 \mathrm{~cm}$. Ten out of every 100 sprouting potato tuber seeds were randomly picked from each lot. The sample size from the seed stores was as indicated in Table 1. Three to five sprouts from each tuber were directly detached into labelled plastic bags ensuring that no sprout was touched with the hands, for the detection of PVX, PVY, PVS, PVA, PVM and PLRV.

\section{Detection of viruses}

Detection of the viruses was done using the DASELISA procedure described by (15) and the results were read using a Bechman photometer at $405 \mathrm{~nm}$. A buffer of $\mathrm{pH} 9.6$ was prepared by dissolving $0.2 \mathrm{~g}$ of $\mathrm{Na}_{2} \mathrm{CO}_{3}, 0.44 \mathrm{~g} \mathrm{NaHCO}_{3}$ and $0.03 \mathrm{~g} \mathrm{NaN}_{3}$ into $30 \mathrm{ml}$ of distilled water. Then 6 times dilution of the buffer with distilled water was made to obtain a coating solution. This solution was then dispensed into six dark bottles, each labelled with one of the six viruses to be detected. Antibody solution was prepared by diluting the different antibodies (PVS-lgG, PVY-lgG, PVX-lgG, PVA-lgG, PVM-lgG and PLRV-lgG) from (CIP, Sigma Lot No. 2004) at a 1:1000 (v/v) in coating solution. Subsequently, $100 \mu \mathrm{L}$ of the solution were dispensed into each micro titre plate well. Filled plates were then placed in a plastic bag and incubated at $37^{\circ} \mathrm{C}$ for $5 \mathrm{~h}$ after which they were emptied and washed thoroughly with phosphatebuffered saline, containing $0.5 \mathrm{ml} . \mathrm{L}^{-1}$ Tween 20 (washing buffer).

Plant extracts were prepared using approximately $0.75 \mathrm{~g}$ of the tuber sprouts which was macerated by rolling a wooden pestle over each sample bag, and $1.5 \mathrm{ml}$ of extraction buffer were added to the sap and homogenised. The sap was then dispensed into the micro titre plate $(100 \mu l /$ well) excluding twelve wells to serve as a control check. Six of the twelve wells were filled with extracts from known diseased plants while the other six were filled with extracts from virus-free plants to serve as positive and negative control checks respectively. Aliquots of each sample were loaded in two micro titre plate wells in each of the six plates labelled with one of the six viruses and the plates incubated at $4{ }^{\circ} \mathrm{C}$ overnight, after which they were washed using the washing buffer. Each corresponding antibody-conjugate was diluted $1 / 300$ in conjugate buffer and $100 \mu \mathrm{L}$ dispensed into each micro titre plate well. The plates were then incubated for 5 hours at $37^{\circ} \mathrm{C}$ after which they were washed and rinsed using the washing buffer.

After the addition of $100 \mu$ of a solution of 0.75 $\mathrm{mg} / \mathrm{ml}$ p-nitro phenyl phosphate per $\mathrm{ml}$ of substrate buffer (100 $\mathrm{g} / \mathrm{l}$ diethanolamine, adjusted to $\mathrm{pH} 9.8$ with hydrochloric acid, and containing $0.5 \mathrm{~g} / \mathrm{l}$ sodium azide), the results were read with the naked eye and confirmed with a suitable photometer at $405 \mathrm{~nm}, 5-10 \mathrm{~min}$. at room temperature and recorded as positive $(+)$ or negative (-) for wells with a yellow colouration or without any colour change, respectively.

\section{Statistical analysis of data}

The Generalized Linear Module (GLM) of the Statistical Analysis System (SAS) was used for the analysis of data. From ANOVA means were separated by Duncan's Multiple Range Test (DMRT). 


\section{RESULTS}

Figure 1 presents the relative prevalence of the viruses in all potato tubers in the stores. Upper Farm at had $82 \%$ prevalence, being significantly higher than that of the other three seed stores, while Rock Farm had the lowest virus prevalence (55\%).

Also the trend observed with the individual viruses presents PVM as the most prevalent virus in three of the four seed stores, highest in Upper farm store $(100 \%)$ and lowest $(85 \%)$ in Rock farm and Rutvitangtah stores. The most prevalent virus in potato tubers from Ruhvitangtah was PVA (88\%) while PLRV (32\%) was the least prevalent compared with all the other viruses tested. A relative prevalence of the viruses is presented in Figure 2. Generally PVX (90\%) and PVS (89\%) were the most prevalent viruses among seed potato tubers in the sampled area, while PLRV $(35 \%)$ was the least prevalent.

The variation in the prevalence of the viruses relative to tuber size is shown in Figure 3. Significant differences were observed in the prevalence of potato viruses in different sizes of potato seed tubers tested. Small sized tubers had the highest prevalence of the viruses $(71 \%)$, while medium and large sized tubers recorded $68 \%$ and $63 \%$, respectively.

The trend of general virus prevalence with respect to tuber sizes, with all the tubers grouped together in Figure 3 is different with regards to seed stores, except for Ruhvitangtah. Virus prevalence was highest in medium size tubers in Upper farm and Rock farm, and in large size tubers from Wara as shown in Figure 4.

Table 1: Number of potato seed tubers $\left(1 / 10^{\text {th }}\right.$ of the total number per seed lot per store) randomly picked from the seed stores according to the three tuber sizes.

\begin{tabular}{|l|l|l|l|l|}
\hline Potato seed stores & No of small tubers & $\begin{array}{l}\text { No of medium } \\
\text { tubers }\end{array}$ & $\begin{array}{l}\text { No of Large } \\
\text { tubers }\end{array}$ & $\begin{array}{l}\text { Total number of } \\
\text { tubers sampled }\end{array}$ \\
\hline Upper Farm & 130 & 125 & 120 & 375 \\
\hline Ruhvitangtah & 100 & 100 & 100 & 300 \\
\hline Wara & 70 & 70 & 60 & 200 \\
\hline Rock Farm & 100 & 100 & 100 & 300 \\
\hline Total per seed size & 400 & 395 & 380 & 1175 \\
\hline
\end{tabular}

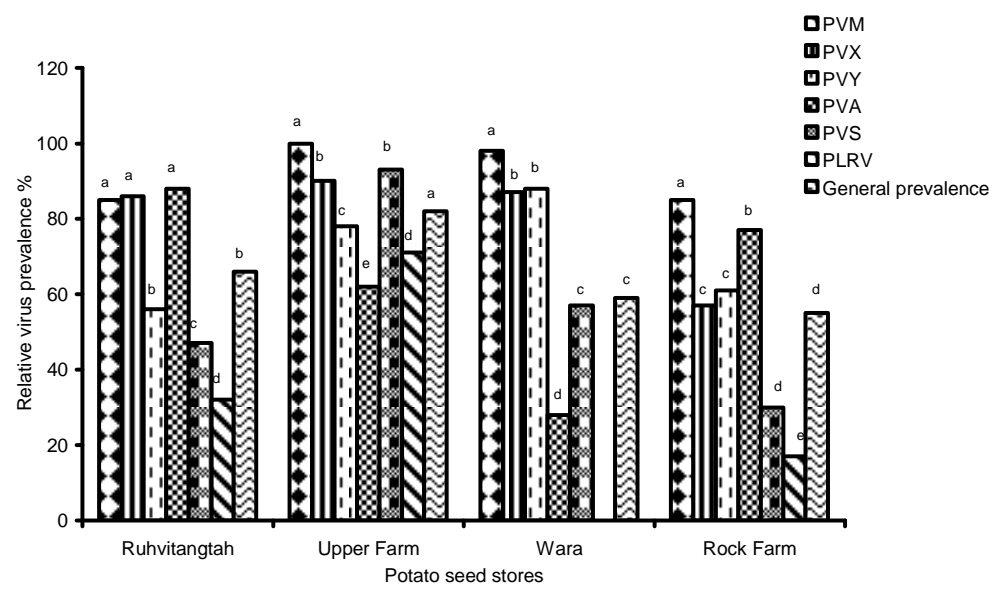

Fig. 1: Percentage virus prevalence per seed store for the six individual potato viruses in the seed tubers tested. Bars with the same letter (a, b, c, d, and e) are not significantly different according to Duncan's Multiple Range Test. The individual viruses are compared within each tuber size, and all the tuber sizes compared for percentage virus prevalence. 


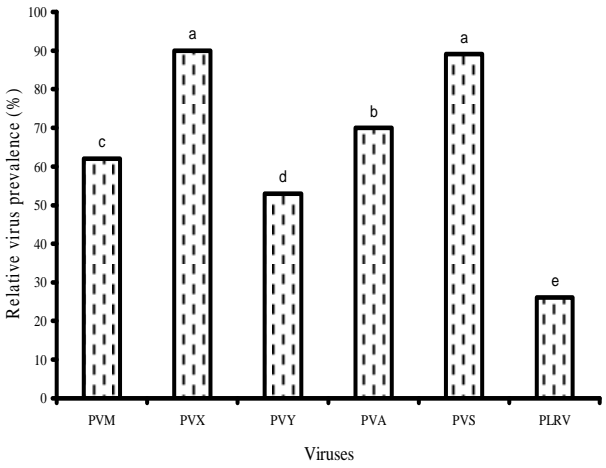

Fig. 2: Relative prevalence of the six potato viruses in all potato tubers tested. Bars with the same letter $(a, b, c$, $\mathrm{d}$, and e) are not significantly different according to Duncan Multiple Range Test

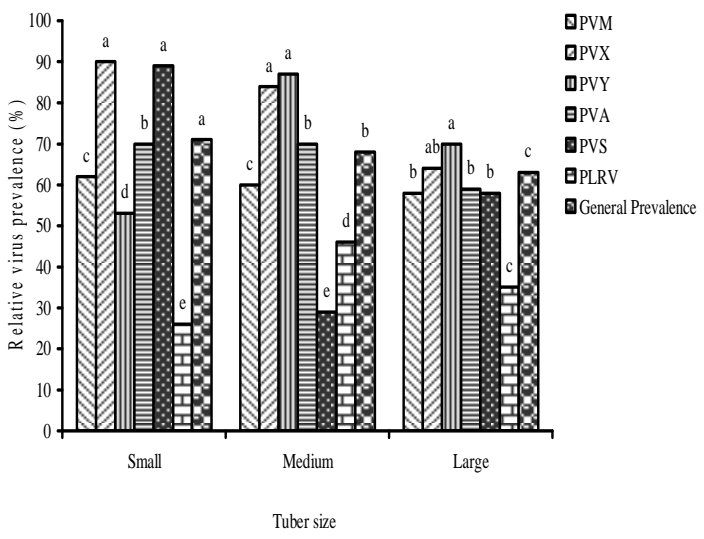

Fig. 3: Percentage virus prevalence and the six individual viruses in small (diameter about $3 \mathrm{~cm}$ ), medium (diameter about $5.5 \mathrm{~cm}$ ), and large (diameter $\geq 8 \mathrm{~cm}$ ) size potato seed tubers from the four seed stores sampled. Bars with the same letter ( $a, b$, and $c$ ) are not significantly different according to Duncan's Multiple Range Test. The individual viruses are compared within each tuber size, and all the tuber sizes compared for percentage prevalence.

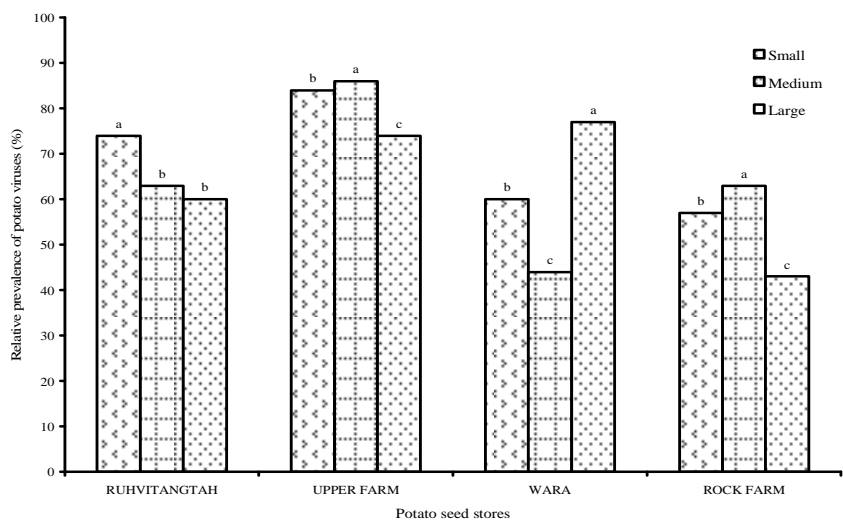

Fig. 4: Relative prevalence of potato viruses in small (diameter about $3 \mathrm{~cm}$ ), medium (diameter about $5.5 \mathrm{~cm}$ ), and large (diameter $\geq 8 \mathrm{~cm}$ ) size potato tubers from each seed store sampled. Bars with the same letter $(a, b$, and c) are not significantly different according to Duncan's Multiple Range Test. 


\section{DISCUSSION}

Virus diseases seriously reduce potato production in the North West Region of Cameroon. The results of this study showed the presence of all six viruses in the study area. This agrees with earlier reports on the occurrence of the six viruses in all areas where potato is grown (1). Each sample tested was infected with 1-6 viruses except two tubers that were negative for all the viruses tested. A report from (16) on the prevalence of these viruses in 2,905 seed potato samples in Peru showed only 142 uninfected potato samples. Collaborating the latter with this study suggest that potato seed tubers are often infected with one or more viruses wherever potato is cultivated.

Significant differences observed in the relative prevalence of the viruses within and among seed stores, might be explained by the kind of interactions that usually occur among factors including the environment, viruses, vectors and the host plants (17). The manual handling tubers by storekeepers and farmers as well as vector population could also have been of significant importance.

Variations in the relative prevalence of viruses in potato seed tubers from the different seed stores can be explained by the factors determining virus infection and spread in the locations where the tubers were harvested. A report by Wood and Jellis (1984 (18), described the incidence of viruliferous aphid vectors early in the growing season as the most significant of all interacting factors that enhance virus spread. The high incidence of PVM, PVX, PVA and PVS could therefore be explained by the fact that they are transmitted mechanically and also by aphids. Aphids move from virus source plants or tubers to healthy plants or tubers and increase transmission. A report by (1) also linked high infections to the feeding habits of aphids. Seed transmission is important for the survival and dissemination of these viruses and is most serious when a vector is present and might also be a reason for their high relative prevalence $(19 ; 10)$.

There were significant differences in the prevalence of viruses in the different tuber sizes. Relative prevalence of viruses was inversely related to tuber size, which agrees with the idea that virus infections lead to low yield and reduction in tuber size. However, (9) linked the high proportion of viruses in small tubers to the fact that they are often the last to be formed and have a greater chance of carrying late primary infections. Farmers in Sub Saharan Africa often obtain planting material by saving small size tubers from the harvest of table potato crops, and selling larger size tubers for consumption. This practice leads to an unconscious selection bias for infected potato tubers for seed, since viruses like PLRV cause a high proportion of disease in small size tubers (20). This may be the more likely reason for high prevalence of viruses, though the lack of good seed production practices also accrues. This results in a correspondingly higher primary inoculum in the field; thus, increasing secondary spread.

Most of the seeds tested showed high mixed virus infections. The presence of mixed infections of PLRV and PVY especially calls for the implementation of urgent control measures if the health status of potato planting materials is to be improved. (21) described PLRV and PVY as the most damaging potato viruses and reported a $60 \%$ yield loss for fields planted with PLRV infected tubers. (22) reported $80 \%$ and $90 \%$ yield losses for PVY and PLRV respectively. The lowest percentage infection was recorded by PLRV, being generally less than $50 \%$ except in Upper Farm where it was up to $71 \%$. The relatively low prevalence of PLRV in this study is likely due to the fact that PLRV is not transmitted mechanically (13) hence, handling tubers or storing them together does not spread the virus.

The prevalence of the six potato viruses (PVA, PVM, PVS, PVY, PVX and PLRV) is high in potato in the North West Region of Cameroon. A similar study conducted by (23) on 10 seed potato tuber stocks from North West and West Regions of Cameroon revealed lower virus infection rates that ranged across seed stocks from $0.00 \%$ to $43.75 \%$ (with a mean of $7.08 \%$ ), $0.00 \%$ to $4.17 \%$ (mean of $0.83 \%$ ), $0.00 \%$ to $27.08 \%$ (mean of $4.37 \%$ ), for PLRV, PVY and PVX, PVA, PVS, respectively. The present study conducted five years later reveals higher virus incidence levels. This can be explained by the quasi absence of virus control measure especially in farmers' fields, since most farmers cannot recognize symptoms of viruses.

This study suggests the urgent need to improve the quality of potato seed either by replacing present seed stocks or improving the sanitary status of the seeds by a systematic seed 
improvement program. The use of healthy seeds at planting and effective control of virus spread, remain the most effective methods of reducing virus diseases.

\section{RECOMMENDATION}

Based on this study, it is recommended that (i) Existing informal seed growers as well as other farmers who save seed tubers from ware potato crops be trained on the use of existing simple techniques (positive and negative selection) to control virus diseases in planting materials, (ii) Larger potato tubers that are less likely virus source be used as planting material for the next planting season if seed tubers have to be obtained from a potato crop in which no seed selection method was used during the growing season.

\section{References}

1. Struik P.C., Wiersema S.G. 1999. Seed Potato Technology. Wageningen Pers, wageningen, The Netherlands.

2. FAOSTAT: Production-Crops, 2010 data". Food and Agriculture Organization of the United Nations. 2011.

3. CIP(Centre International de la Pomme de Terre). 1999. Program report: 1993-1994. Lima, Peru.

4. Harold J., Judith A., Pavis J. 1997. Annotated bibliography of nematode pest of potato. Lima, Peru. 315p

5. Schippers R. 1998. Cash Cropping Study in Enugu Nigeria. Preliminary overview of field studies. $78 \mathrm{p}$.

6. Horton D. 1992. La papa: Produccion, commercialization y programas. In: Potato viruses and their control L. F. Salazar, (ed). CIP, Lima, Peru. $214 \mathrm{p}$.

7. Acquah E., Lyonga S. 1994. Internal Review of the Tropical Root and Tubers Research Project. 78 p.

8. Foncho P.A.F. 1989. Future plans and strategies for potato research in Cameroon.

9. Salazar L. 1996. Potato Viruses and their Control. ISBN, Lima, Peru. 214 p.

10. Salazar L., Jayasinghe (eds) (1997) Techniques in Plant Virology. Training manual.CIP, Lima, Peru
11. Kotheka V. 1986. Systematics, Breeding and Seed Production of Potatoes. Bulletin of Applied botany, genetics and breeding. ISBN, Balkema /Rotterdam, India. Vol. 62 Number 1, 293 p.Poppe J. 1985. Phytovirologie, Phytomycologie. University Of Dschang, Cameroon. $85 \mathrm{p}$.

12. Nienhaus F. 1981. Virus and Similar Diseases in Tropical and Subtropical Areas. GTZ, Eschborn 1Germany.

13. Bilgrami K, Dube H. 1984. A Textbook of Modern Plant Pathology. Shahdara, India. 344 p.

14. Bar-Joseph M, Garnsey S.M. 1981. Enzymelinked immunosorbent assay (ELISA): Principles and applications for diagnosis of plant viruses. In: $\mathrm{K}$ Maramorosch, KF Harris (eds) Plant diseases and vectors: ecology and epidemiology. Academic Presse, New York, 35-59

15. CIP (Centre International de la Pomme de Terre), 1995. Program report: 1993-1994. Lima, Peru. $192 \mathrm{p}$.

16. Bos L. 1983. Introduction to Plant Virology. Centre for agricultural publishing and Documentation. Wageningen, the Netherlands. pp 8-43.

17. Wood R., Jellis K. 1984. Plant diseases: Infection, damage and loss. ISBN, Britain.

18. Allen D., Thottapilly G., Rossel H. 1982. Cowpea mottle virus: Field resistance and seed transmission in virus tolerant cowpea. Ann. of App. Biol. 100: 311-336.

19. Mih A., Atiri G. 2003. An overview of Irish potato viruses and virus diseases. In: Proceedings of Plant Virology in Sub Saharan Africa (PVSSA). Hughes J d'A, Odu B O (eds). IITA. Ibadan Nigeria, June 4-8, 2001. 334-341

20. Jellis G., Boulton R. 1984. Damage and Loss caused by Potato Diseases. ISBN, Britain. 255265

21. CIP (Centre International de la Pomme de Terre), 1993. Annual Report. Lima, Peru. 164 p.

22. Demo P, Njualem D. 2001. Results of virus testing of seed potato samples collected from multipliers seed stocks in the West and North West Provinces of Cameroon. Activity report. Cameroon Potato Program, IRAD Bambui, Cmaeroon. 